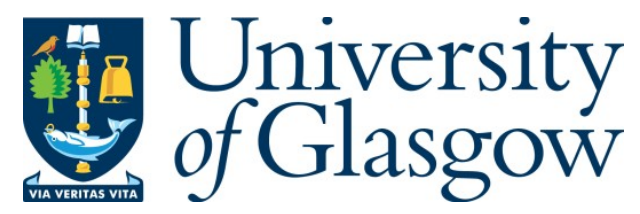

Dawson, M. (2021) Bauman, Elias and Latour on Modernity and Its Alternatives: Three Contemporary Sociological Theorists on Modernity and Other Options, by Sandro Segre. Contemporary Sociology, 50(6), pp. 511-512. [Book Review]

(doi: 10.1177/00943061211050046t)

This is the Author Accepted Manuscript.

There may be differences between this version and the published version. You are advised to consult the publisher's version if you wish to cite from it.

http://eprints.gla.ac.uk/227449/

Deposited on: 7 January 2021

Enlighten - Research publications by members of the University of Glasgow http://eprints.gla.ac.uk 
Bauman, Elias and Latour on Modernity and its Alternatives: Three Contemporary Sociological Theorists on Modernity and Other Options, by Sandro Serge. London: Anthem Press, 2020. 104 pp. \$79.95 cloth. IBSN: 9781758273049.

\section{Matt Dawson}

University of Glasgow

Matt.dawson@glasgow.ac.uk

The title of Bauman, Elias and Latour on Modernity and its Alternatives: Three Contemporary Sociological Theorists on Modernity and Other Options is enticing, Bauman, Elias and Latour form a triptych of intriguingly distinct social theorists. The inclusion of Latour, a fundamentally different type of thinker from the other two, and someone often missing from writings on modernity is of note here. Any reader would be interested to see what exactly we can learn about Latour, Bauman and Elias by putting them in discussion with each other. This is especially enticing when we focus the discussion on the central sociological concept of modernity. Unfortunately, while this book does provide valuable introductions to the work of each writer and their critics, it does not fulfill the initial intrigue of its title.

Largely, this disappointment is due to the format of the text. This is a short book and Serge has decided to use this limited space to provide introductory comments on each writer. As he puts it at the end of his text, this book 'has been deliberately not critical or judgmental of any author' (p. 97). This reflects what the reader will find in the sections on each theorist who are discussed in separate chapters of roughly 30 pages each (bookended by a one-page Preface and seven-page Conclusion). For each writer Serge begins with a broad discussion of their epistemological basis, before turning to how they conceive of society. He then turns to substantive topics in their work (such as Latour's work on Pasteur or Elias' book on Germany) before highlighting criticisms offered by other writers. Each chapter is comprehensive and runs across each writer's oeuvre effectively, but the breadth of the discussion and lack of evaluation can be somewhat dizzying. For example, each criticism section is, in effect, a list of different critical studies, each given roughly a short paragraph and with no links drawn across them. This is valuable if one wants an expanded annotated bibliography in order to know the key critical studies, but the lack of synthesis leaves one unclear on what this body of critical literature says about the value of each writer's work.

This broad stroke discussion of each writer also raises questions about why the book is framed as discussing 'modernity and its alternatives'. To start with modernity, as the above has indicated, this concept does not provide the frame for the chapters dedicated to each theorist, these are broader in nature. Indeed, when modernity is mentioned in these chapters, it is, especially for Bauman and Elias, underdeveloped. The Bauman chapter, while highlighting that he speaks of solid, post and liquid modernity, does not interrogate how each concept is related to each other, beyond highlighting that they suggest different societies. When it comes to Elias, modernity is not mentioned as a concept until the concluding section of the chapter where Serge notes that 'the very notion of modernity plays as such no role in Elias's sociology' (p. 61). Without any development of how Elias may theorise modernity without using the concept, this leaves the reader wondering why Serge included him in such a 
study. The discussion of Latour does include a useful discussion of his rejection of modernity as a concept but given this is part of a broader discussion of his work, the reader is left unclear why the title of this book was not Bauman, Elias and Latour on Society.

Such a title would still seem to hold out the possibilities of cross-discussion and synthesis. However, there is little discussion of the writers in comparison to each other here. This happens across five pages in the Conclusion, where Serge notes that Elias and Bauman share some features, most notably concerning Germany and the Holocaust - frustratingly, Bauman's multiple writings on Elias where, among other comments, he most notably draws out the value of the concept of figuration, are accorded just one paragraph earlier in the text (p. 57) - while Latour is more radical in rejecting the concept of modernity. Earlier it is suggested that this radicalism flows from his discussion of non-human actors which Elias, and presumably Bauman, does not discuss (p. 73). This is then followed by a brief comparison with Foucault and Giddens. As with the main writers of this book, it is unclear why these writers were chosen or what is gained from a two-page discussion at the end of the book. Perhaps then a clearer title would highlight that these are Introductions to Bauman, Elias and Latour on Society?

It is also unclear what the 'alternatives' of Serge title are. He suggests that 'the set of alternatives is then as follows: modernity versus postmodernity (Bauman); civilization versus barbarity (Elias); successful versus unsuccessful hybrids (Latour)' (p. 91). This just poses further questions as to what is meant by 'alternative'. Bauman would not say post, or liquid, modernity is an alternative to (solid) modernity. Instead, these are distinct forms of the same process of modernization which happen alongside each other, emphasized to different degrees. Since, as Serge notes, Elias doesn't discuss modernity the reader is led to assume 'civilization' stands in for this, in which case, to what extent is barbarity an 'alternative', in the sense that Luxemburg may have opposed it to socialism for instance, or a 'predecessor'? For Latour, I would suggest his conception of the social is his alternative to modernity. In each case, it is unclear how Serge defines 'alternatives'. Are these, as the inclusion of 'other options' suggests in the subtitle, the different possibilities or actualities which can/have occurred in opposition to modernity, or is it instead a way to highlight that dualities mark out each writers work? If the latter, we could then perhaps extend our new title for this book to Introductions to Bauman, Elias and Latour on Society and its Dualities. A title such as that would fit more clearly the content of the book.

As this review has indicated, a reader of this text would leave confused about the conflict between its title and content. If a reader were interested in reading a comprehensive introductory overview of each of the theorists discussed here along with a list of their key critics - such a reader would be perhaps a student coming to grips with each theorist, or a scholar beginning to dip their toes into their work - this text does have clear value and can be recommended as such. If, however, one is after an interrogation of the value of the concept of modernity or already has knowledge of each writer and is intrigued by the insights that can be gained from discussing them together, this will be a very frustrating read. A different framing and structure to this work, which would fit the former set of needs rather than the latter, would have made for a clearer text. 